\title{
Nutrient Uptake and Soil Health under Chemical and Non-Chemical Weed Management Practices in Irrigated Rice Ecosystem
}

\author{
Himanshu Verma*, S.P. Singh, V.P. Singh, B.S. Mahapatra, \\ Sirazuddin, Neeshu Joshi and Aaradhana Chilwal
}

\author{
Department of Agronomy, Govind Ballabh Pant University of Agriculture and Technology, \\ Pantnagar 263145, Uttarakhand, India \\ *Corresponding author
}

\section{A B S T R A C T}

\begin{tabular}{|l|}
\hline Key w o r d s \\
Nutrient uptake, \\
Soil health, \\
Weeds, Irrigated \\
ecosystem, \\
Aerobic rice.
\end{tabular}

A field experiment was conducted during kharif season of 2014 at Dr. N. E. Borlaug Crop Research Centre of G. B. Pant University of Agriculture and Technology Pantnagar, District Udham Singh Nagar (Uttarakhand) to evaluate the effect of different chemical and non-chemical methods of weed control on nutrient uptake by weeds and aerobic rice and impact of various weed control treatments on rhizospheric soil microorganism viz. bacteria, fungi and actinomycetes. Lowest uptake of nitrogen by weeds was found in plots treated with pendimethalin (30 EC) @ $1.25 \mathrm{~kg} / \mathrm{ha}$ fb one HW followed by weed free while lowest uptake of phosphorous and potassium by weeds were recorded in weed free plots followed by pendimethalin (30 EC) @ $1.25 \mathrm{~kg} / \mathrm{ha}$ fb one HW. Highest uptake of nitrogen, phosphorous and potassium by crop was recorded in plots treated with by pendimethalin (30 EC) @ $1.25 \mathrm{~kg} / \mathrm{ha} \mathrm{fb}$ one HW. Highest population of bacteria was recorded under weedy check followed by weed free and wheat straw mulch (4t/ha) fb one HW. Maximum fungal population was recorded in Sesbania co-culture fb pendimethalin (30 EC) @ 1.25 $\mathrm{kg} / \mathrm{ha} \mathrm{fb} 2$, 4- D (38 EC) @ $0.5 \mathrm{~kg} / \mathrm{ha}$ while maximum population of actinomycetes was recorded in wheat straw mulch $(4 \mathrm{t} / \mathrm{ha}) \mathrm{fb}$ one $\mathrm{HW}$.

\section{Introduction}

Rice is one of the most important food crops in the world, and staple for more than half of the global population. Looming water crisis, water-intensive nature of rice cultivation and escalating labour costs drive the search for alternative management methods to increase water productivity in rice cultivation. Direct seeded rice (DSR) has received much attention because of its low-input demand. It involves sowing pre-germinated seed into a puddled soil surface (wet seeding), standing water (water seeding) or dry seeding into a prepared seedbed (dry seeding). Weeds are one of the major constraints in aerobic rice production as they reduce productivity due to competition, allelopathy, by providing habitats for pathogens as well as serving as alternate host for various insects and fungi and increase harvest cost. Studies indicated that crop losses due to weed competition throughout the world as a whole, are greater than those resulting from combined effect of insect pests and diseases. Weeds that grow with the crop deplete considerable amount of plant nutrients, which results in lower crop yields. Nutrient depletion by weeds, besides 
other factors, depends on soil type and composition of weeds. Residual effect of herbicides may cause considerable decrease in soil microbial population that are known for improving soil fertility thereby non-chemical weed management approach can be adopted. Therefore present research was carried out to study the effect of chemical and non-chemical weed management practices on nutrient uptake by weeds and rice crop and also its effect on soil health.

\section{Materials and Methods}

Field experiments were carried out at N.E. Borlaug, Crop Research Centre, G. B. P. U. A \& T, Pantnagar during kharif 2014 in a Randomized Block Design with ten treatments and three replications. The study site is located in tarai (young alluvial soil mollisol with shallow to medium water table) belt of India and is characterized by sub humid and sub- tropical climate. During 2014, the maximum and minimum temperature were ranging $29.1-41.3{ }^{0} \mathrm{C}$ and $15.5-26.9{ }^{0} \mathrm{C}$ respectively. Ten treatments viz. weedy check; wheat straw mulch $(4 \mathrm{t} / \mathrm{ha}) \mathrm{fb}$ one hand weeding (25 DAS); wheat straw mulch (4 t/ha) fb fenoxaprop @ $60 \mathrm{~g}$ a.i/ha; Sesbania co-culture fb cono weeder (25 DAS) fb one hand weeding (50 DAS); pendimethalin @ $1.25 \mathrm{~kg}$ a.i/ha fb one hand weeding (25 DAS); pendimethalin @ $1.25 \mathrm{~kg}$ a.i/ha fb cono weeder (25 DAS); Sesbania co-culture fb pendimethalin@1.25 kg a.i/ha fb 2,4-D@ $0.5 \mathrm{~kg}$ a.i/ha; bispyribac sodium @ $20 \mathrm{~g}$ a.i/ha; tank mix of fenoxaprop @ $60 \mathrm{~g}$ and 2, 4 - D@0.5 kg /ha and weed free are used in experiment with randomized block design ( $\mathrm{R}$. B. D) with three replications. Variety of rice and Sesbania was Sarjoo-52 and Pant Ses-1 respectively.

Nitrogen, phosphorous and potassium uptake by the crop and weeds at maturity stage was determined by using modified micro
Kjeldhals method, Vanado -molybdophosphoric yellow colour method and flame emission photometry method respectively and expressed in $\mathrm{kg} / \mathrm{ha}$. Total bacterial, fungal and actinomycetes populations were enumerated using serial dilution technique and pour plate method. After appropriate incubation period, the colonies of microorganism appearing on plates were counted following standard method (Pramer and Schmidit, 1964). Nutrient agar medium (Johnson and Curl, 1972) was used for total bacterial count, martin's dextrose rose agar medium and starch ammonium agar medium were used for fungi and actinomycetes, respectively.

\section{Results and Discussion}

\section{Nutrient uptake by weeds}

Weed management practices had significantly affected on nutrients ( $\mathrm{N}, \mathrm{P}$ and $\mathrm{K}$ ) uptake by weeds at 100 DAS. The highest uptake of nitrogen (44.48 kg/ha), phosphorus (10.69 $\mathrm{kg} / \mathrm{ha})$ and potassium (58.82 $\mathrm{kg} / \mathrm{ha})$ was noticed under weedy check. Highest uptake of $\mathrm{N}, \mathrm{P}$ and $\mathrm{K}$ in weedy check plots may be due to luxuriant growth of weeds, which accumulated higher dry matter. The results are in conformity with those of Singh et al., (2005a). Lowest uptake of nitrogen was found in plots treated with pendimethalin (30 EC) @ $1.25 \mathrm{~kg} / \mathrm{ha} \mathrm{fb}$ hand weeding (25 DAS) followed by weed free plots while phosphorus and potassium uptake was recorded lowest in weed free plots (Table 1). This might have happened due to utilization of space efficiently by rice crop due to good growth habit in weed free situation as well as treated with pendimethalin which reduce the density and dry matter of weeds hence lower uptake of N, P and K by weeds. Similar findings were reported by Sharif et al., (2014). Sudhalaxhmi et al., (2005) also reported that weeds uptake heavy dose of nutrients from the soil as compared to crop plants. 
Table.1 Effect of treatments on nutrient uptake by weeds ( $\mathrm{kg} / \mathrm{ha})$ at maturity stage

\begin{tabular}{|c|l|c|c|c|}
\hline \multicolumn{1}{|c|}{ Treatments } & $\mathrm{N}(\mathrm{kg} / \mathrm{ha})$ & $\mathrm{P}(\mathrm{kg} / \mathrm{ha})$ & $\mathrm{K}(\mathrm{kg} / \mathrm{ha})$ \\
\hline $\mathrm{T} 1$ & Weedy Check & 44.5 & 10.7 & 58.8 \\
\hline $\mathrm{T} 2$ & WS fb HW (25 DAS) & 15.4 & 3.42 & 18.1 \\
\hline $\mathrm{T} 3$ & WS fb FP @ 60 g ai/ha & 15.5 & 2.98 & 17.8 \\
\hline $\mathrm{T} 4$ & Ses fb CW(25 DAS) fb HW (50 DAS) & 15.7 & 2.82 & 15.6 \\
\hline $\mathrm{T} 5$ & Pendi @ 1.25 kg/ha fb HW(25 DAS) & 8.20 & 2.70 & 11.8 \\
\hline $\mathrm{T}_{6}$ & Pendi @1.25 kg/ha fb CW(25 DAS) & 12.7 & 2.74 & 14.1 \\
\hline $\mathrm{T} 7$ & Ses fb Pendi @ 1.25 kg/ha fb 2,4-D @ 0.5 kg ai /ha & 18.9 & 3.81 & 19.5 \\
\hline $\mathrm{T} 8$ & BS @ 20 g ai/ha & 11.0 & 2.51 & 12.4 \\
\hline $\mathrm{T} 9$ & Tank mix of FP @ 60 g ai/ha and 2,4-D @ 0.5 kg ai/ha & 17.2 & 3.77 & 18.7 \\
\hline $\mathrm{T}_{10}$ & Weed free SEm \pm & 8.57 & 2.10 & 10.9 \\
\hline \multicolumn{2}{|c|}{ CD at 5\% } & 0.42 & 0.14 & 0.36 \\
\hline
\end{tabular}

WS- Wheat straw mulch (4 t/ha), FP- Fenoxaprop-p-ethyl (9.3 EC), Pendi- Pendimethalin (30 EC), CW- Cono weeder, HW- Hand weeding, BS- Bispyribac sodium (10 SC), 2,4-D- 2,4 dichlorophenoxy acidic acid(38 EC), Ses- Sesbania co-culture, fb- followed by, DAS- days after sowing

Table.2 Effect of treatments on Nitrogen uptake by crop ( $\mathrm{kg} / \mathrm{ha})$ at maturity

\begin{tabular}{|l|l|c|c|r|}
\hline & Treatments & Grain & Straw & Total \\
\hline $\mathrm{T} 1$ & Weedy Check & 35.9 & 26.2 & 62.1 \\
\hline $\mathrm{T} 2$ & WS fb HW (25 DAS) & 41.3 & 42.9 & 84.2 \\
\hline $\mathrm{T} 3$ & WS fb FP @ 60 g ai/ha & 45.5 & 42.9 & 88.4 \\
\hline $\mathrm{T} 4$ & Ses fb CW(25 DAS) fb HW (50 DAS) & 47.2 & 49.3 & 96.5 \\
\hline $\mathrm{T} 5$ & Pendi @ 1.25 kg/ha fb HW(25 DAS) & 51.6 & 64.6 & 116.2 \\
\hline $\mathrm{T} 6$ & Pendi @ 1.25 kg/ha fb CW(25 DAS) & 48.4 & 50.7 & 99.0 \\
\hline $\mathrm{T} 7$ & Ses fb Pendi @ 1.25 kg/ha fb 2,4-D @ 0.5 kg ai /ha & 43.7 & 34.2 & 77.9 \\
\hline $\mathrm{T}_{8}$ & BS @ 20 g ai/ha & 52.3 & 52.7 & 105.0 \\
\hline $\mathrm{T} 9$ & Tank mix of FP @ 60 g ai/ha \& 2,4-D @ 0.5 kg ai/ha & 41.2 & 36.7 & 77.9 \\
\hline $\mathrm{T}_{10}$ & Weed free & 51.7 & 64.9 & 116.6 \\
\hline \multicolumn{1}{c|}{ SEm \pm} & 0.61 & 0.71 & 0.81 \\
\hline & \multicolumn{1}{|c|}{ CD at 5\% } & 1.81 & 2.12 & 2.40 \\
\hline
\end{tabular}

WS- Wheat straw mulch (4 t/ha), FP- Fenoxaprop-p-ethyl (9.3 EC), Pendi- Pendimethalin (30 EC), CW- Cono weeder, HW- Hand weeding, BS- Bispyribac sodium (10 SC), 2,4-D- 2,4 dichlorophenoxy acidic acid(38 EC), Ses- Sesbania co-culture, fb- followed by, DAS-days after sowing 
Table.3 Effect of treatments on phosphorus uptake by crop $(\mathrm{kg} / \mathrm{ha})$ at maturity

\begin{tabular}{|c|l|c|c|c|}
\hline & Treatments & Grain & Straw & Total \\
\hline $\mathrm{T}_{1}$ & Weedy Check & 10.5 & 5.8 & 16.3 \\
\hline $\mathrm{T}_{2}$ & WS fb HW (25 DAS) & 13.2 & 10.2 & 23.4 \\
\hline $\mathrm{T}_{3}$ & WS fb FP @ 60 g ai/ha & 14.0 & 10.7 & 24.7 \\
\hline $\mathrm{T}_{4}$ & Ses fb CW(25 DAS) fb HW (50 DAS) & 14.7 & 12.6 & 27.3 \\
\hline $\mathrm{T}_{5}$ & Pendi @1.25 kg/ha fb HW(25 DAS) & 18.4 & 14.1 & 32.5 \\
\hline $\mathrm{T}_{6}$ & Pendi @1.25 kg/ha fb CW(25 DAS) & 15.3 & 12.8 & 28.1 \\
\hline $\mathrm{T}_{7}$ & Ses fb Pendi @ 1.25 kg/ha fb 2,4-D @ 0.5 kg ai /ha & 12.3 & 8.5 & 20.8 \\
\hline $\mathrm{T}_{8}$ & BS @ 20 g ai/ha & 15.7 & 13.2 & 28.9 \\
\hline $\mathrm{T}_{9}$ & Tank mix of FP @ 60 g ai/ha \& 2,4-D @ 0.5 kg ai/ha & 13.0 & 9.2 & 22.2 \\
\hline $\mathrm{T}_{10}$ & Weed free & 18.2 & 15.8 & 34.0 \\
\hline & SEm \pm & 0.30 & 0.32 & 0.45 \\
\hline & $\mathrm{CD}$ at 5\% & 0.88 & 0.96 & 1.35 \\
\hline
\end{tabular}

WS- Wheat straw mulch (4 t/ha), FP- Fenoxaprop-p-ethyl (9.3 EC), Pendi- Pendimethalin (30 EC), CW- Cono weeder, HW- Hand weeding, BS- Bispyribac sodium (10 SC), 2,4-D- 2,4 dichlorophenoxy acidic acid (38 EC), Ses- Sesbania co-culture, fb- followed by, DAS-days after sowing

Table.4 Effect of treatments on potassium uptake $(\mathrm{kg} / \mathrm{ha})$ by crop at maturity

\begin{tabular}{|l|l|c|c|c|}
\hline & Treatments & Grain & Straw & Total \\
\hline T1 & Weedy Check & 13.1 & 14.7 & 27.8 \\
\hline T2 & WS fb HW (25 DAS) & 16.0 & 22.1 & 38.1 \\
\hline T3 & WS fb FP @ 60 g ai/ha & 16.2 & 23.5 & 39.8 \\
\hline T4 & Ses fb CW(25 DAS) fb HW (50 DAS) & 17.7 & 27.3 & 45.0 \\
\hline T5 & Pendi @1.25 kg/ha fb HW(25 DAS) & 19.8 & 32.7 & 52.6 \\
\hline T6 & Pendi @1.25 kg/ha fb CW(25 DAS) & 17.7 & 28.0 & 45.7 \\
\hline T7 & Ses fb Pendi @ 1.25 kg/ha fb 2,4-D @ 0.5 kg ai /ha & 14.0 & 20.8 & 34.8 \\
\hline T8 & BS @ 20 g ai/ha & 18.8 & 28.8 & 47.6 \\
\hline T9 & Tank mix of FP @ 60 g ai/ha \& 2,4-D @ 0.5 kg ai/ha & 15.4 & 20.5 & 35.9 \\
\hline$T_{10}$ & Weed free & 20.7 & 34.2 & 54.9 \\
\hline & SEm \pm & 0.24 & 0.46 & 0.56 \\
\hline
\end{tabular}

WS- Wheat straw mulch (4 t/ha), FP- Fenoxaprop-p-ethyl (9.3 EC), Pendi- Pendimethalin (30 EC), CW- Cono weeder, HW- Hand weeding, BS- Bispyribac sodium (10 SC), 2,4-D- 2,4 dichlorophenoxy acidic acid(38 EC), Ses- Sesbania co-culture, fb- followed by, DAS-days after sowing. 
Table.5 Effect of treatments on soil microbial population at 50 days stage of crop growth

\begin{tabular}{|l|l|c|c|c|}
\hline \multicolumn{2}{|l|}{} & Bacteria log cfu & Fungi log cfu & $\begin{array}{c}\text { Actinomycetes } \\
\log \text { cfu }\end{array}$ \\
\hline$T$ Treatments & Weedy Check & 8.05 & 4.44 & 6.22 \\
\hline$T 2$ & WS fb HW (25 DAS) & 8.02 & 4.44 & 6.22 \\
\hline$T 3$ & WS fb FP @ 60 g ai/ha & 7.98 & 4.41 & 6.21 \\
\hline$T 4$ & $\begin{array}{l}\text { Ses fb CW(25 DAS) i HW (50 } \\
\text { DAS) }\end{array}$ & 8.01 & 4.43 & 6.22 \\
\hline$T 5$ & Pendi @ 1.25 kg/ha fb HW(25 DAS) & 8.01 & 4.38 & 6.20 \\
\hline$T 6$ & Pendi @ 1.25 kg/ha fb CW(25 DAS) & 7.97 & 4.42 & 6.20 \\
\hline$T 7$ & $\begin{array}{l}\text { Ses fb Pendi @ 1.25 kg/ha fb 2,4- D } \\
\text { @ 0.5 kg ai /ha }\end{array}$ & 7.96 & 4.45 & 6.21 \\
\hline$T 8$ & BS @ 20 g ai/ha & 8.01 & 4.37 & 6.22 \\
\hline$T 9$ & $\begin{array}{l}\text { Tank mix of FP @ 60 g ai/ha and } \\
\text { 2,4-D @ 0.5 kg ai/ha }\end{array}$ & 7.97 & 4.37 & 6.22 \\
\hline$T_{10}$ & Weed free SEm \pm & 8.02 & 4.44 & 6.22 \\
\hline & \multicolumn{1}{|c|}{} & 0.00 & 0.01 & 0.00 \\
\hline & CD at 5\% & 0.01 & 0.02 & 0.01 \\
\hline
\end{tabular}

WS- wheat straw mulch (4 t/ha), FP- fenoxaprop-p-ethyl (9.3 EC), Pendi- pendimethalin (30 EC), CW- cono weeder, HW- hand weeding, BS- bispyribac sodium (10 SC), 2,4-D- 2,4 dichlorophenoxy acidic acid(38 EC), Ses- Sesbania co-culture, fb- followed by, DAS-days after sowing.

Nutrient uptake by rice

\section{Nitrogen uptake by rice $(\mathrm{kg} / \mathrm{ha})$}

Weed management practices significantly influenced the nitrogen uptake $(\mathrm{kg} / \mathrm{ha})$ in grain, straw and total at maturity. Highest nitrogen uptake in grain was recorded in weed free plot which was statistically at par with bispyribac sodium (10 SC) @ $20 \mathrm{~g} / \mathrm{ha}$ and pendimethalin (30 EC) @ $1.25 \mathrm{~kg} / \mathrm{ha} \mathrm{fb}$ hand weeding (25 DAS) while nitrogen uptake $(\mathrm{kg} / \mathrm{ha})$ by straw and plant in weed free plot was statistically at par with pendimethalin (30 EC) @ $1.25 \mathrm{~kg} / \mathrm{ha} \mathrm{fb}$ hand weeding (25 DAS).

This might be due to effectively control of weeds by applying pendimethalin (30 EC) @ $1.25 \mathrm{~kg} / \mathrm{ha}$. Similar results were observed by Bahar et al., 2004 who reported that pre emergence application of pendimethalin produced significantly higher grain yield and lesser weed dry weight, thereby increasing uptake of nutrients by crop and lesser uptake by weed plants (Table 2 ).

Phosphorus uptake by crop (kg/ha) at maturity

Weed management practices significantly influenced the phosphorus uptake $(\mathrm{kg} / \mathrm{ha})$ in grain, straw and total at harvest.

Among various treatments highest phosphorus uptake in grains was recorded in pendimethalin (30 EC) @ $1.25 \mathrm{~kg} / \mathrm{ha}$ fb hand weeding (25 DAS) which was statistically at par with weed free while phosphorous uptake by straw and total was recorded highest in weed free plot followed by pendimethalin (30 EC) @ $1.25 \mathrm{~kg} / \mathrm{ha} \mathrm{fb}$ hand weeding (25 DAS) (Table 3). 


\section{Potassium uptake by crop (kg/ha)}

Weed management practices significantly influenced potassium uptake $(\mathrm{kg} / \mathrm{ha})$ in grain, straw and total at maturity.

Among various treatments, highest potassium uptake $(\mathrm{kg} / \mathrm{ha})$ in grain, straw and total was recorded in weed free plot followed by pendimethalin (30 EC) @ $1.25 \mathrm{~kg} / \mathrm{ha} \mathrm{fb}$ hand weeding and bispyribac sodium (10 SC) @ 20 $\mathrm{g} / \mathrm{ha}$ (Table 4).

\section{Effect on soil microorganisms}

All weed management practices significantly influenced microbe's population (bacteria, fungi and actinomycetes) at 50 days stage of crop growth. Highest population of bacteria was recorded in weedy check followed by weed free and wheat straw mulch (4 t/ha) fb hand weeding (25 DAS) (Table 5).

Lowest bacterial population was reported in Sesbania co-culture $\mathrm{fb}$ pendimethalin (30 EC) @ $1.25 \mathrm{~kg} / \mathrm{ha} \mathrm{fb} 2,4-\mathrm{D}$ (38 EC) @ $0.5 \mathrm{~kg}$ /ha. Similar findings were in line with Bera and Ghosh, 2013 who reported that herbicide did not show any significant influence on population of total bacteria in the rhizosphere of rice soil at initial stage (zero days after application) but after application of herbicides in soil, slight variations were found between the treated and non-treated plots and growth of total bacterial population decreased in herbicidal treated plots.

Maximum fungal population was recorded in Sesbania co-culture $\mathrm{fb}$ pendimethalin (30 EC) @ $1.25 \mathrm{~kg} / \mathrm{ha} \mathrm{fb} 2,4-\mathrm{D}$ (38 EC) @ $0.5 \mathrm{~kg}$ /ha. This might be due to less adverse impact of pendimethalin applied at recommended rate, i.e., $1.25 \mathrm{~kg} / \mathrm{ha}$ on soil fungal colonies also timely hand weeding or cono weeding which increased microbial population by improving aeration and soil health.
Based on the result of present investigation, it was concluded that highest uptake of nitrogen, phosphorous and potassium by weeds was noticed under weedy check situation while lowest uptake by weeds and highest uptake by rice crop was found in pendimethalin (30 EC) @ $1.25 \mathrm{~kg} / \mathrm{ha} \mathrm{fb}$ one HW. Highest population of rhizospheric soil microorganism was recorded in non- chemical weed management practices compared with chemical weed management. Maximum population of these microorganisms was found in weed free and weedy check situation. Thus it can be concluded that nonchemical methods of weed control in aerobic rice under irrigated condition had lesser adverse impact on soil microbes.

\section{References}

Bahar FA and Singh G (2004). Effect of Herbicides on Dry Seeded Rice and Associated Weeds. Indian Journal of Weed Science. 36(3 \& 4): 269-270.

Bera S and Ghosh RK (2013). Soil physicochemical properties and microflora as influenced by bispyribac- Na $10 \%$ SC in transplanted kharif rice. Rice science. 20(4): 289-302.

Bindra AD, Kalia BD and Shekhar J (2002). Bio-Efficacy of Promising Herbicidal Molecules in Direct-Seeded Sprouted Puddled Rice. Indian Journal of Weed Sceince.34 (1\&2): 39-41.

Fuka S. (2002). Rice cultivar requirements for direct seeding in rainfed lowlands. In: Pandey S, Mortimer M, Wade L, Tuong TP, Lopes K, Hardy B (eds.) Direct Seeding: Research Strategies and Opportunities. International Rice Research Institute, Los Banos, Philippines, pp. 257-269.

Hussain S, Ramzan M, Akhter M and Aslam $M$ (2008). Weed management in direct seeded rice. Journal of Animal and Plant Science. 18(2-3). 
Jha B K (2009). Effect of herbicide application in soybean on productivity and soil health. Master thesis (soil science) submitted to gbpuat, Pantnagar, Udham Singh Nagar, Uttarakhand. pp: $23-31$

Johnson IF and Curl EA (1972). Methods for research on ecology of soil borne plant pathogens. Burges publishing Co., Minneapolis.

Maity SK and Mukerjee PK (2008). Integrated weed management in dry direct seeded rainy season rice. Indian Journal of Agronomy. 53(2): 116-120.

Pramer D and Schmidt EL (1964). Experimental soil microbiology. Burges Publishing Co., U.S.A.

Puniya R, Pandey PC, Bisht PS and Singh DK (2007). Nutrient uptake by crop and weeds as influenced by Trisulfuron, Trisulfuron + Pretilachlor and Bensulfuron-methyl in transplanted rice (Oryza sativa L.). Indian Journal of Weed Science. 39(3\&4): 239-240.

Rao AN and Nagamani A (2007). Available technologies and future research challenges for managing weeds in dryseeded rice in India.In Proc. of the 21st Asian Pacific WeedScience Society Conference. 2 to 6th October 2007,
Colombo, Sri Lanka. pp.391-400.

Rao AN, Johnson DE, Sivaprasad B, Ladha JK and Mortimer AM (2007). Weed management in direct-seeded rice. Advances in Agronomy. 93: 153-255.

Sharif A and Chauhan SB (2014). Performance of different herbicides in dry seeded rice in Bangladesh.The scientific world Journal. Article ID 729418.

Singh G, Singh OP, Kumar J, Mehta RK, Kumar V and Singh PP (2005 a). Effect of weed management practices on direct seeded rice (Oryza sativa) under puddled low lands. Indian Journ al of Agronomy. 50: 35-37.

Singh S, Bhusan L, Ladha JK, Gupta RK, Rao AN and Sivprasad B (2005 b).Weed management in dry seeded rice (Oryza sativa) cultivated in the furrow-irrigated raised-bed planting system. www. elsevier.com

Sudhalakshmi C, Velu V and Thiyagarajan TM (2005). Weed Management Options on the Dynamics of Nitrogen Fractions in the Rhizosphere Soil of Rice Hybrids. Madras Agricultural Journal. 92(7-9): 444-448.

\section{How to cite this article:}

Himanshu Verma, S.P. Singh, V.P. Singh, B.S. Mahapatra, Sirazuddin, Neeshu Joshi and Aaradhana Chilwal. 2017. Nutrient Uptake and Soil Health under Chemical and Non-Chemical Weed Management Practices in Irrigated Rice Ecosystem. Int.J.Curr.Microbiol.App.Sci. 6(12): 3152-3158. doi: https://doi.org/10.20546/ijcmas.2017.612.368 